\title{
Kepemimpinan Pelatih dalam Pembinaan Olahraga Prestasi
}

\author{
Oleh: \\ Donie \\ Dosen Pendidikan Kepelatihan FIK UNP
}

\section{A. Pendahuluan}

Sejarah panjang perjalanan prestasi olahraga Indonesia mengalami pasang surut prestasi yang semuanya bermuara kebijakan dan implementasinya dalam bentuk pembinaan olahraga. Dimensi dari perjalanan olahraga yang dulunya hanya berorientasi kepada aktifitas jasmani semata, saat ini telah mengalami suatu revolusi yang luar biasa dimana olahraga menjadi bahagian penting dalam aspek kehidupan dan menjadi instrumen penting dari pembangunan suatu bangsa.

Di beberapa negara maju dan saat ini fungsi dari olahraga sudah mengalami yang cukup pesat dan mencengangkan, salah satunya adalah bagaimana olahraga saat ini berkembang menjadi sebuah industri yang jika dikelola secara baik dan benar merupakan salah satu komoditi yang cukup menjanjikan. Hal sudah tidak lagi menjadi rahasia umum bagaimana perputaran finansial dalam jumlah yang fantastis pada beberapa atlet kelas dunia, rekor transfer atlet sepakbola yang luar biasa, kontrak atlet dan bagaimana gila-gilaan suatu produk mempromosikan produknya dengan biaya dan strategi promosi yang cukup tinggi yang kesemuanya menggambarkan bagaimana dahsyatnya industri olahraga yang tidak kalah dengan bisnis otomotif dunia.

Bagi bangsa Indonesia olahraga juga memainkan multifungsi baik sebagai media peningkatan sumber daya manusia Indonesia, sebagai alat perjuangan pada masa sebelum dan sesudah kemerdekaan, sebagai pembentuk karakter bangsa karena olahraga mengandung nilai-nilai universal yang sangat dibutuhkan saat ini yaitu, sportifitas, pantang menyerah dan kerja sama. Bahkan yang tak kalah pentingnya 
adalah olahraga mampu menjadi identitas bangsa serta mampu mengangkat harkat dan martabat bangsa Indonesia sama dengan yang lainnya.

Salah satu pidato dari presiden Republik Indonesia pertama, Presiden Soekarno terkait dengan pembentukan nasionalisme dan harkat martabat bangsa adalah:

"'engkau adalah olahragawan, itulah kau punya wilayah tetapi dedication of ;lifemu harus untuk indonesia. Nah itulah pesan yang akan aku berikan pada saat sekarang ini, dengan harapan agar supaya kita nanti bukan saja di dalam pertandingan-pertandingan Asian games, Tetapi seharusnya kita, membangun suatu nation Indonesia, Nation Building Indonesia, yang membuat bangsabangsa yang mulia, bangsa yang tegak berdiri, bangsa yang bahagia"

Pidato yang diucapkan pada tanggal 9 April 1961, merupakan pidato yang sangat menggugah kontingen Indonesia khususnya para atlet sehingga mampu tampil secara heroik, menorehkan tinta emas dalam sejarah panjang perjalanan olahraga Indonesia sampai sekarang, Indonesia menjadi peringkat ke-2 pada Asian Games ke IV di Jakarta pada saat itu.

Namun penegasan arti penting dari olahraga oleh bangsa Indonesia secara yuridis, baru 41 tahun kemudian diwujudkan dengan lahirnya salah satu sumber hukum yaitu dengan lahirnya Undang-undang Nomor 3 tentang Sistem Keolahragaan Nasional. Dalam undang-undang ini dikatakan bahwa tujuan Keolahragaan Nasional adalah:

"memelihara dan meningkatkan kesehatan dan kebugaran, prestasi, kualitas manusia, menanamkan nilai moral dan akhlak mulia, sportivitas, disiplin, mempererat dan membina persatuan dan kesatuan bangsa, memperkukuh ketahanan nasional, serta mengangkat harkat, martabat, dan kehormatan bangsa"

Dari tujuan keolahragaan Nasional yang diamanatkan oleh Undang undang Sistem Keolahragaan Nasional ada 5 point penting dari tujuan keolahragaan nasional yaitu:

1. memelihara dan meningkatkan kesehatan dan kebugaran,

2. Untuk meningkatkan Prestasi

3. Meningkatkan Kualitas Manusia 
4. Pembentukan Karakter melalui menanamkan nilai moral dan akhlak mulia, sportivitas, disiplin,

5. Dan National Building dengan membina persatuan dan kesatuan bangsa, memperkukuh ketahanan nasional, serta mengangkat harkat, martabat, dan kehormatan bangsa."

Tujuan keolahragan ini sangat lengkap jika dikaitkan dengan peningkatan kualitas manusia Indonesia sebagai manusia pembangunan yang memiliki kualitas jasmani yang sehat, berkarakter dan memiliki semangat nasionalisme yang tinggi terhadap NKRI. Untuk mewujudkan tujuan keolahragaan nasional tentu tidak mungkin hanya dimainkan oleh satu atau beberapa orang, namun membutuhkan suatu kolaborasi dari seluruh pelaku olahraga yang merupakan orang atau kelompok orang yang terlibat secara langsung dalam kegiatan olahraga yang meliputi pengolahraga, pembina olahraga, dan tenaga keolahragaan. Selanjutnya tenaga keolahragaan terdiri dari pelatih, guru/dosen, wasit, juri, manajer, promotor, administrator, pemandu, penyuluh, instruktur, tenaga medis dan para medis, ahli gizi, ahli biomekanika, psikolog, atau sebutan lain yang sesuai dengan kekhususannya serta berpartisipasi dalam menyelenggarakan kegiatan olahraga.

Pelatih adalah salah satunya sebagai tokoh yang sangat berperan dalam melahirkan atlet-atlet hebat kelas dunia seperti : Roger Federer di cabang olahraga tenis, Michael Jordan pada cabang bolabasket, Tiger Wood di golf, dan Taufik Hidayat di bulutangkis dan lain sebagainya. Semua atlet-atlet kelas dunia tersebut merupakan atlet-atlet terbaik pada cabang olahraga mereka masing masing, yang mampu memberikan kebanggaan baik secara individu maupun kebanggaan sebagai sebuah negara.

Namun dibalik prestasi yang membanggakan itu, banyak yang terlupakan tentang tokoh penting dibalik layar, tokoh kunci yang sangat berperan dalam melahirkan atlet-atlet terbaik kelas dunia tersebut. Pelatih merupakan salah satu orang dibalik layar yang mampu mengangkat secara perlahan tapi pasti level prestasi atlet tersebut, mulai dari tahap pemula sampai si atlet tersebut menjadi atlet elit nantinya. Pelatih yang berkualitas diharapkan akan melahirkan prestasi yang berkualitas juga yang kesemuanya akan di dapat melalui latihan yang berkualitas tentunya. Latihan yang berkualitas adalah latihan yang sesuai dengan tahapan periodisasi serta di dukung 
oleh berbagai disiplin ilmu akan membawa atlet secara perlahan tetapi pasti menuju ke prestasi yang membanggakan tadi.

Salah satu tugas utama dari pelatih adalah pemimpin bagi para atletnya, Kepemimpinan adalah suatu "proses dimana seseorang dapat menjadi pemimpin (leader) melalui aktivitas yang terus menerus sehingga dapat mempengaruhi yang dipimpinnya dalam rangka untuk mencapai tujuan organisasi". Bagi pelatih yang memimpin para atlet baik di luar dan di dalam lapangan harus senantiasa mampu untuk terus membawa atletnya sesuai dengan tujuan yang diharapkannya. Keberhasilan pelatih dalam mencapai tujuan tersebut sangat dipengaruhi oleh gaya kepemimpinan yang merupakan model kepemimpinan dalam mempengaruhi kelompoknya khususnya para atlet untuk mencapai prestasi yang diharapkan. Gaya kepemimpinan ini akan sangat membantu pelatih dalam merealisasikan program yang disusun karena akan berpengaruh besar kepada diri atlet yang dipengaruhinya untuk berbuat, berjalan, bertindak dan berlatih sesuai dengan yang diharapkan pelatih tersebut. Dibutuhkan pengetahuan berupa ilmu dan seni dalam merealisasikan kepemimpinan tersebut dalam bentuk gaya atau tipe kepemimpinan yang efektif dalam mewujudkan prestasi yang diharapkan

Brooks dan Fahey (1984) mengemukakan bahwa pelatih mempunyai tugas sebagai perencana, pemimpin, teman, pembimbing, dan pengontrol program latihan. Sedangkan atlet mempunyai tugas melakukan latihan sesuai program yang telah ditentukan pelatih. Banyak cara pendekatan dilakukan pelatih dalam merealisasikan program yang telah disusun, antara lain yaitu melalui gaya (style) yang merupakan cara kerja yang biasa dilakukan sebagai kekhasan dari seseorang. Menyadari bahwa pelatih adalah individu yang memiliki karakteristik khas berbeda satu dengan yang lainnya. Perbedaan tersebut disebabkan oleh berbagai hal termasuk latar belakang kehidupan baik pengalaman hidup yang dilalui maupun latar belakang pendidikan yang juga akan mempengaruhi pola bertindak termasuk dalam menerapkan gaya kepemimpinan pelatih tersebut kepada atletnya di lapangan.

Fungsi pelatih sebagai pemimpin menarik untuk dikaji dan dievaluasi, karena salah satu kunci utama dalam keberhasilan para atlet terletak pada kemampuan seorang pelatih dalam memimpin atletnya. Hal ini tercermin dari interaksi yang terjadi di 
lapangan. Pelatih mempunyai tugas sebagai perencana, pemimpin, teman, pembimbing, dan pengontrol program latihan. Sedangkan atlet mempunyai tugas melakukan latihan sesuai program yang telah ditentukan pelatih. 


\section{B. PEMBAHASAN}

\section{Kompetensi Pelatih}

Pelatih adalah orang penting di balik kesuksesan prestasi seorang atlet. Dibalik prestasi yang fenomenal, di balik atlet yang sukses, dibelakangnya pastilah berdiri seorang pelatih yang baik. Masih banyak pakar yang kebingungan dalam memberikan batasan tentang kompetensi, apakah kompetensi tersebut karakterik organisasi ataupun karakteristik kerja. Kesulitan dalam mendefenisikan atau merumuskan pengertian dari kompetensi dikarenakan bahwa kompetensi memiliki defenisi yang luas dan mencakup berbagai aspek.

The British National Council of vocational Qualifications merumuskan pengertian kompetensi sebagai kemampuan untuk melaksanakan kegiatan kegiatan kerja sesuai dengan standar yang diperlukan. Sedangkan menurut Australia's National Training Board mengatakan bawa kompetensi terdiri dari spesifikasi pengetahuan dan keterampilan serta penerapan pengetahiuan dan keterampilan tersebut pada standar kinerja yang dipersyaratkan.

Selajutnya terkait dengan pengertian kompetensi tersebut, Sedarmayanti, (2004) menyimpulkan beberapa pendapat ahli terkait dengan kompetensi yaitu:

1. Konsep luas, memuat kemampuan mentransfer keahlian dan kemampuan kepada situasi baru dalam wilayah kerja, menyangkut organisasi dan perencanaan pekerjaan, inovasi dan mengatasi aktivitas rutin, kualitas efektivitas personel yang dibutuhkan di tempat berkaitan deugan rekan kerja. Menejer serta pelanggan.

2. Kemampuan dan kemauan untuk melakukan tugas

3. Dimensi perilaku yang mempengaruhi kinerja .

4. Karakteristik individu apapun yang dapat dihitung dan diukur secara konsisten, dapat dibuktikan untuk membedakan secara signifikan antara kinerja yang efektif dengan yang tidak efektif. 
5. Kemampuan dasar dan kualitas kinerja yang diperlukan untuk mengerjakan pekerjaan dengan baik.

6. Bakat, sifat dan keahlian individu apapun yang dapat dibuktikan. dapat dihubungkan dengan kinerja yang efektif dan baik sekali.

Berdasarkan uraian tersebut. Sedarmayanti menyimpulkan secara menyeluruh bahwa kompetensi merupakan faktor mendasar yang perlu dimiliki seseorang sehingga mempunyai kemampuan lebih dan membuatnya berbeda dengan seseorang yang mempunyai kemampuan rata-rata atau biasa saja. Sedarmayanti (2004) mengatakan bahwa cakupan dari kompetensi tersebut adalah

1. Motif (motive), yaitu kebutuhan dasar seseorang yang mengarahkain cara berfikir dan bersikap.

2. Sifat-sifat dasar (Trait), yaitu yang menentukan cara seseorang bertindak/tingkah laku.

3. Citra pribadi (Self image), yaitu pandangan seseorang terhadap identitas dan kepribadiannya sendiri atau inner-self.

4. Peran kemasyarakatan (Social role), yaitu bagaimana seseorang melihat dirinya dallam interaksinya dengan orang lain atau outer-self.

5. Pengetahuan (Knowledge), yaitu sesuatu yang dapat dimanfaatkan dalam tugas/pekerjaan tertentu

6. Keterampilan (Skills), yaitu kemampuan teknis untuk melakukan sesuatu dengan baik.

Berdasarkan uraian tersebut, dapat diketahui bahwa kompetensi memiliki cakupan yang sangat kompleks. pada awalnya adalah kemampuan atau karakteristik dasar yang dimiliki seseorang tetapi dapat dikembangkan menjadi lebih baik sesuai dengan kebutuhannya. Selanjutnya terkait dengan elemen elemen atau faktor faktor yang turut mempengaruhi dari kompetensi, dalam Undang Undang Sistem Keolahragaan Nasional juga dikatakan bahwa Elemen-elemen kompetensi terdiri atas Pasal 2 ayat 2

a. Landasan kepribadian; 
b. Penguasaan ilmu dan keterampilan;

c. Kemampuan berkarya;

d. Sikap dan perilaku dalam berkarya menurut tingkat keahlian berdasarkan ilmu dan keterampilan yang dikuasai;

e. Pemahaman kaidah berkehidupan bermasyarakat sesuai dengan pilihan keahlian dalam berkarya.

Dalam dunia kepelatihan olahraga terkait dengan kompetensi ini secara nayata dituangkan dalam anatomi pelatih bahwa pelatih yang baik haru memiliki anatomi yang merupakan kompetensi yang harus dimilki oleh seorang pelatih seperti gambar berikut:

\section{An Anatomy of a Good Coach}

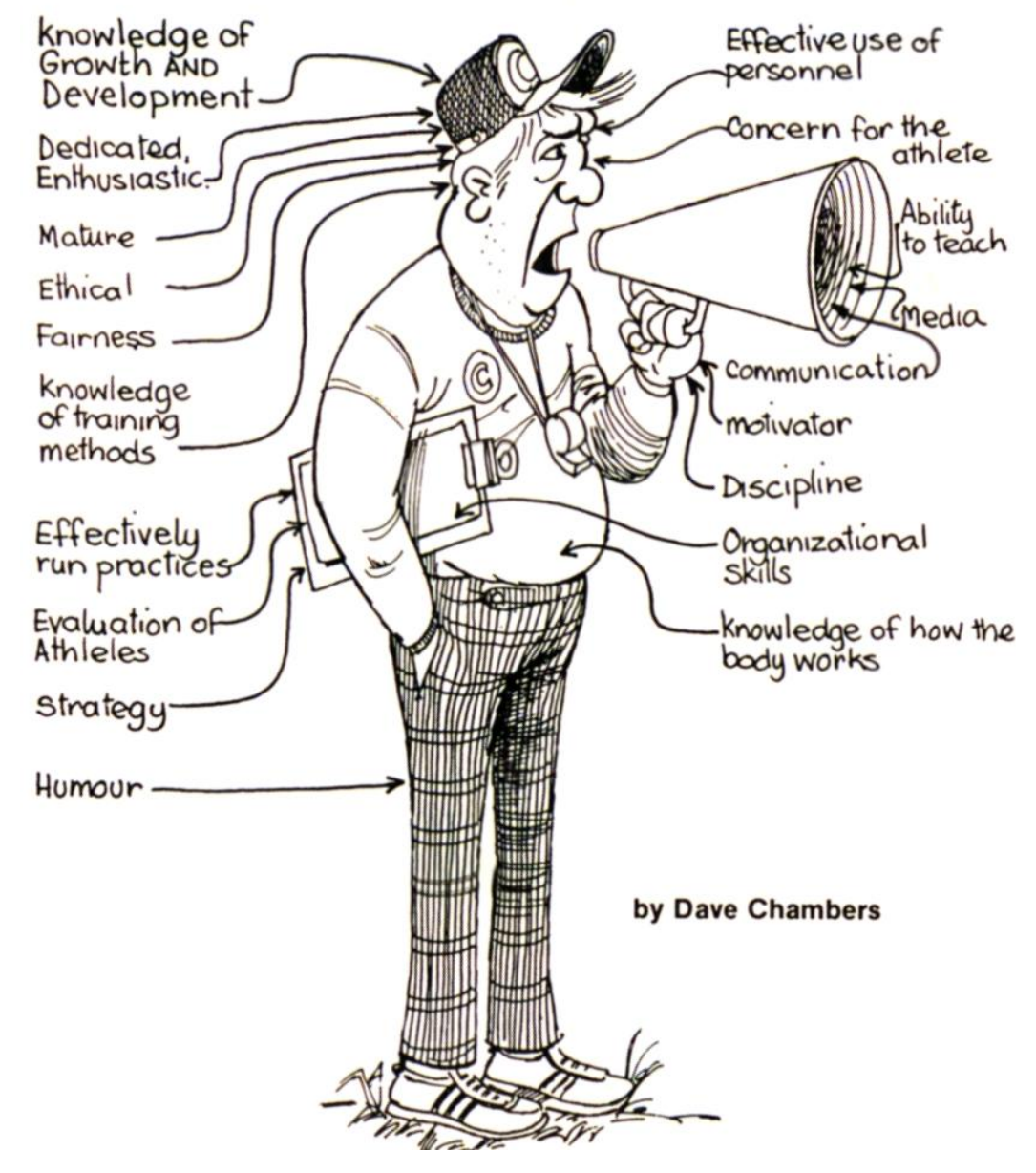


Dalam gambar tersebut disebutkan bahwa anatomi pelatih yang baik harus memiliki beberapa karakteristik yang merupakan kompetensi penting yang harus imiliki dan terus dikembangkan oleh seorang pelatih yaitu:

Pengetahuan akan pertumbuhan dan perkembangan

1) Dedikasi dan antusias yang tinggi

2) Kematangan

3) Etika

4) Berikap adil

5) Pengetahuan akan metoda latihan

6) Efektifitas dalam pemberdayaan personel

7) Fokus terhadap atlet

8) Pengelolaan Media

9) Kemampuan berkomunikasi

10) Menjalankan prakteknya dengan efektif

11) Kemampuan mengevaluasi atlet

12) Kemampuan memahami dan mengaplikasikan strategi

13) Menjadi motivator

14) Meletakan dan menjalankan disiplin

15) Keterampilan mengorganisasi

16) Pengetahuan bagaimana tubuh bekerja

17) Memiliki selera humor

\section{Kinerja Pelatih}


Kebutuhan yang paling penting dalam mengembangkan atlet pada level yang lebih baik lagi adalah ketersediaan pelatih yang handal dan baik. Kita menyadari bahwa pembinaan prestasi atet sangat membutuhkan pelatih yang memiliki berpengetahuan, motivasi, intens, peka terhadap kebutuhan individu, dan sukses dalam memecahkan masalah, suasana latihan yang mampu mendukung pencapaian prestasi atlet. Sebaliknya Jika pelatih memiliki pengetahuan teknis atau teoritis yang buruk, kurang pengalaman, tidak mampu untuk merencanakan program yang komprehensif, atau memiliki motivasi, atau tidak bisa mengelola waktu dengan sebaik baiknya akan berdampak kurang baik terhadap perkembangan prestasi dari atlet yang dibinannya .

Hal ini merupakan kesulitan dan tantangan di negara berkembang untuk menciptakan sebuah sistem untuk mengembangkan pelatih handal atau level tinggi . Tantangan ini harus dicarikan solusi agar pelatih bisa meningkatkan diri sesuai dengan kebutuhan dan fungsi sebagai seorang pelatih yang dibutuhkan oleh para atlet berprestasi

Dikaitkan dengan beberapa pengertian tentang kinerja di atas, kinerja pelatih bisa diartikan sebagai hasil atau outcome dari seseoarang dalam hal ini pelatih dalam menjalankan peran, tugas dan fungsinya sebagai seorang pelatih. Sebagai salah satu orang yang sangat berperan dalam membawa dan membimbing para atlet bimbingannya khususnya dalam peningkatan prestasi olahraga kecabangannya tuntutan dan peran dan fungsi pelatih menjadi sangat penting..

Fungsi dan peran seorang pelatih sangat erat hubungannya dengan capaian prestasi yang diukir oleh atlet. Pelatih adalah seorang yang harus tahu tentang semua kebutuhan yang menjadi dasar bagi terpenuhinya kondisi dimana atlet memiliki peluang untuk mencapai prestasi. Hubungan antara pelatih atlet yang dibina harus merupakan hubungan yang mencerminkan kebersamaan pandangan dalam mewujudkan apa yang dicita-citakan.

Seorang pelatih dituntut mampu menjalani profesinya dengan tidak sematamata bermodalkan dirinya sebagai mantan atlet, melainkan harus melengkapi dirinya dengan seperangkat kompetensi pendukung yang penting, diantaranya adalah kemampuan untuk mentransfer pengetahuan keolahragaannya kepada atlet secara lengkap baik dari segi teknik, taktik, maupun mental. Kemampuan untuk mengorganisir 
dinamika mental atlet merupakan hal yang sangat penting untuk dikuasai pelatih. Kompetensi ini akan lebih banyak terlihat ketika pelatih menghadapi suasana kompetensi yang penuh dengan tekanan. Pengalaman menjadi modal utama dalam menghadapi situasi ini.

Penguasaan kecabangan olahraga dan dalamnya pengalaman tidak sertamerta akan menjadikan dirinya sebagai pelatih yang dihormati dan disegani kecuali jika dirinya sudah memiliki karakter dan filosofi sebagai seorang pelatih. Karakter adalah konsistensi sikap dan cara pandang dalam menghadapi suatu masalah. Sedangkan filosofi adalah bingkai kepribadian yang akan menjadi jembatan bagi aktualisasi seluruh komponen yang dimiliki agar apa yang dilakukan dapat diterima oleh orang lain.

Dengan memiliki filosofi seorang melatih akan dapat memiliki pegangan ketika menjalankan tugas profesionalnya. Menyadari pentingnya pengembangan kompetensi pelatih sehingga dalam Undang Undang SKN ditegaskan tentang standar kompetensi (pasal 81). Standar komptetensi dimaksud adalah Standar kompetensi adalah standar nasional yang berkaitan dengan kemampuan minimal yang mencakup pengetahuan, sikap, dan keterampilan yang harus dimiliki seseorang untuk dapat dinyatakan lulus dalam uji kompetensi. Dalam hal ini kompetensi pelatih diartikan juga harus di dasarkan pada pengetahuan sebagai pelatih, sikap sebagai pelatih, dan keterampilan sebagai pelatih.

Pengetahuan sebagai pelatih termasuk dalam hal ini pelatih harus memiliki wawasan yang luas khususnya terkait dengan disiplin ilmu yang dimiliki yang mendukung pelatih dalam melaksanakan tugas kepelatihannya. Pengetahuan dimaksud meliputi pengetahuan tentang ilmu fisiologi olahraga, ilmu melatih, ilmu psikologi, giszi dan lain sebagainya yang kesemuannya dibutuhkan dan harus senantiasa di up date oleh para pelatih dalam menjalankan tugas dan perannya sebagai seorang pelatih.

Sikap pelatih dalam hal ini termasuk didalamnya etika dan estetika dari pelatih. Etika dalam artian pelatih harus mencerminkan nilai-nilai yaang baik yang dijabarkan dalam aturan dan ketentuan serta perbuatan kesehariannya dan harus mencerminkan nilai nilai yang luhur seperti, disiplin, sopan santun, sportifitas dan lain sebagainya. Sedangkan estetika bahwa dalam kesehariannya pelatih harus bisa mencerminkan 
keindahan, kebersihan dan ketertiban baik dalam pengelolaan latihan maupun dalam bertutur kata dalam berkomunikasi

Dalam menjalankan tugas kesehariannya pelatih harus taat pada kode etik yang merupakan sandaran nilai dan etika yang dijadikan pedoman dalam melaksanakan tugas dan perannya. Nilai dan etika pelatih tersebut menurut IOC (2001) adalah sebagai berikut:

1. bertindak dengan integritas dalam melaksanakan semua tugas kepada atlet, olahraga, anggota lain dari profesi pembinaan dan masyarakat

2. berusaha untuk menyiapkan diri dengan sebaik baiknya agar semua tugas yang sesuai dengan disiplin ilmu bisa dipenuhi dengan kompetensi yan dimiliki

3. bertindak mengutamakan i pengembangan atlet sebagai manusia seutuhnya

4. menerima peraturan yang baik yang tertulis maupun yang tidak tertulis dari sebuah pertandingan

5. menerima peran sebagai orang yang memberikan penilaian untuk memastikan bahwa kompetisi dilakukan secara adil

6. Memperlihatkan kepada pelatih dan officil lainnyasebagai pelatih yang sopan, memilki itikat yang baik serta kepeduliaan atau kepekaan.

7. mempertahankan prilaku yang baik dan mendukung prinsip-prinsip fair play

8. menjadi nara sumber yang dapat membantu atlet untuk mengembangkan / nya potensi atletik dan kemampuan diri sendiri

9. mengenali perbedaan individu pada atlet dan selalu berpikir jangka panjang atlet kepentingan terbaik

10. Mendapatkan prestasi terbaik berdasarkan tujuan yang realistis serta dengan memperhatikan pertumbuhan dan perkembangan atlet

11. Memberikan keteladanan dalam kerja saman, disiplin diri, menghormati lawan dan official, dan santun dalam berbahasa, berpakaian dan bertingkah laku 
12. Menciptakan suasana latihan yang menantang dan menyenangkan. Belajar Keterampilan dan teknik tidak harus menyakitkan. Bersikaplah jujur dan konsisten dengan atlet: tahu dengan posisi sebagai seoarang pelatih.

13. Menyiapkan diri untuk bisa berinteraksi dengan media, official dan orang tua, mereka juga memiliki peran penting untuk menegakan peratuaran dalam permainan

14. memastikan bahwa tidak ada pelecehan dari bentuk apapun dalama lingkungan olahraga.

Hal inilah yang senantiasa harus dipedomani, di jaga dan ditumbuhkembangkan oleh pelatih sebagai pemimpin dalam usaha meningkatkan prestasi atlet dan juga sebagai orang anggota masyarakat dengan yang harus memilki pola berfikir dan bertingkah laku yang baik tentunya.

Pelatih yang baik tentunya adalah pelatih yang memiliki keinginan dan kemampuan untuk berkembangn baik secara pengetahuan dan keterampilan ke arah yang lebih baik lagi. Pelatih yang handal harus memiliki atribut sebagai pelatih berkinerja tinggi diantaranya yaitu:

1. Standar pengetahuan yang diperlukan

2. Bersedia untuk melakukan pekerjaan yang diperlukan

3. Tidak ada kompromi ... bergairah

4. Mampu meyakinkan atlet untuk mengikuti aturan dan perintahnya

5. Terorganisir ... fokus

6. Pemecah masalah ... praktis ... mencarikan jalan keluar

7. Menguasai olahraga

8. Mempertahankan kontrol secara keseluruhan

9. Percaya diri dalam bertindak

10. Berpengalaman dalam taktik (IOC: 2001) 
Dari kesepuluh atribut pelatih berkinerja tinggi tersebut dapat disimpulkan bahwa pelatih harus memilki pengetahuan dan keterampilan kecabangan, pribadi yang kuat untuk memimpin dan mengendalikan latihan dan atlet, serta kesadaran diri dan tanggung jawab untuk senantiasa mengembagkan diri demi peningkatan prestasi atlet.

Secara ringkas dari berbagai aspek tersebut terkait dengan peran dan tugas pelatih sebagai pemimpin menurut Tahir Djide dalam Harsuki (2003) menyebutkan:

a. Cermat menentukan sasaran atau tujuan latihan

b. Menetapkan tujuan latihan yang bersifat realitik

c. Memilih metode, model model, yang cocok untuk memenuhi kebutuhan setiap pemain

d. Memotivasi pemain untuk berlatih keras

e. Mencermati latihan pemanasan (warm up) dan pencegahan cidera (avoid Injury)

f. Istirahat dan minum yang cukup

g. Memanfaatkan aspek pembinaan psikologis

h. Cermat dan terampil melakukan seni berkomunikasi

Tugas dan peran inilah yang harus dipahami dan dijalankan oleh pelatih dalam upaya mewujudkan kinerja pelatih tersebut di lapangan. Hal ini jugalah yang menuntut pelatih harus senantiasa beruapaya meningkatkan kemampuan kinerja dan kompetensi diri guna mewujudkan tugas dan peran sebagai seorang pelatih dan pemimpin yang baik

\section{Kepemimpinan Pelatih}

a. Pengertian Gaya Kepemimpinan

Kepemimpinan merupakan suatu faktor penting yang dibutuhkan dalam sebuah organisasi. Keberhasilan sebuah organisasi sagat ditentukan oleh kecakapan pemimpin dalam mempegaruhi, mengajak dan membawa semua anggota yang ada dalam organisasi tersebut, sesuai dengan tujuan dari organisasi tersebut.

Namun tidak semua orang bisa untuk jadi seorang pemimpin, dalam beberapa teori kepemimpinan dikatakan bahwa pemimpin dilahirkan dan di ciptakan. Dilahirkan dalam artian bahwa seseorang tersebut secara alamiah dan keturunan memang memiliki kemampuan sebagai pemimpin karena mewarisi darah sebagai seorang 
pemimpin. Disisi lain ada pemimpin yang diciptakan, dalam artin bahwa pemimpin tersebut lahir karena sebuah proses dan dipengaruhi oleh lingkungan. Dalam proses tersebut termasuk pendidikan di dalamnya sangat mempengaruhi dalam proses pembentukan seseorang menjadi seorang pemimpin.

Kepemimpinan berasal dari kata pimpin yang mengandung 2 pokok pikiran penting yaitu pemimpin sebagai subyek dan pemimpin sebagai objek. Kata pimpinan mengandung pengertian mengarahkan, membina atau mengatur, menuntun dan menunjukan ataupun mempengaruhi. Pemimpin mempunyai tanggugjawab baik secara fisik maupun secara spritual terhadap keberhasilan dan aktivitas kerja dari orang -orang yang dipimpinnya.

Pemimpin yang efektif adalah pemimpin yang anggotanya dapat merasakan bahwa kebutuhan mereka terpenuhi, baik kebutuhan bekerja, motivasi, rekreasi, kesehatan, sandang, pangan, tempat tinggal maupun kebutuhan lainnya yang pantas dapatkan. Artinya semua kebutuhan anggota dalam organisasi dapat terpenuhi dengan baik (Husdarta: 2011)

Terry dalam Winardi (1999) memberikan batasan " kepemimpian adalah hubungan dimana satu orang yakni pemimpin mempengaruhi pihak lain untuk bekerja sama secara sukarela dalam usaha mencapai hal yang diiinginkan oleh pemimpin tersebut.. Selanjuntnya menurut William Newman (1968) dalam Miftah (2003) kepemimpinan adalah kegiatan untuk mempengaruhi perilaku orang lain atau seni mempengaruhi perilaku manusia baik perorangan maupun kelompok. Dan satu hal yang perlu diingat bahwa kepemimpinan tidak harus dibatasi oleh aturan-aturan atau tata karma birokrasi. Kepemimpinan bisa terjadi dimana saja, asalkan seseorang menunjukkan kemampuannya mempengaruhi perilaku orang lain ke arah tercapainya suatu tujuan tertentu.

Lebih spesifik Wirawan mendefenisikan kepemimpinan sebagai pola perilaku pemimpin dalam mempengaruhi para pengikutnya. Pola prilaku bukan dalam pengertian yang statis tetap dalam pengertian yang dinamis, karena gaya kepemimpinan seseoarang dapat berubah ubah tergantung pengikut dan situasinya. 
Selanjutnya Wirawan memberikan batasan tentang bahwa gaya kepemimpinan merupakan adonan dari sejumlah perilaku kepemimpinan diantaranya: (a) perilaku menganalisis karakteristik; (b) perilaku memilih dan menggunakan kekuasaaan; (c) perilaku memilih dan meggunakan teknik mempegaruhi; (d) perilaku penggunaan karakteristik pribadi; (e) perilaku menganalisis hasi mempengaruhi dan (f) perilaku mengevaluasi hasil kepemimpinan

Bahasan mengenai pemimpin dan kepemimpinan pada umumnya menjelaskan bagaimana untuk menjadi pemimpin yang baik, gaya dan sifat yang sesuai dengan kepemimpinan serta syarat-syarat apa yang perlu dimiliki oleh seorang pemimpin yang baik. Meskipun demikian masih tetap sulit untuk menerapkan seluruhnya, sehingga dalam prakteknya hanya beberapa pemimpin saja yang dapat melaksanakan kepemimpinannya dengan baik dan dapat membawa para pengikutnya kepada keadaan yang diinginkan. Kepemimpinan dapat dikategorikan sebagai ilmu sosial terapan (applied social sciences). Hal ini didasarkan kepada pemikiran bahwa kepemimpinan dengan prinsip-prinsipnya mempunyai manfaat langsung dan tidak langsung terhadap upaya mewujudkan kesejahteraan umat manusia.

Teori kepemimpinan berdasarkan ciri (traits theory) memberi petunjuk tentang ciri-ciri pemimpin yaitu (Siagian, 2003):

a. Pengetahuan umum yang luas.

b. Kemampuan untuk tumbuh dan berkembang.

c. Kemampuan analitik.

d. Sifat inkuisitif atau rasa ingin tahu.

e. Keterampilan berkomunikasi secara efektif.

f. Kemampuan menentukan skala prioritas.

g. Rasionalitas.

h. Keteladanan.

i. Ketegasan.

j. Orientasi masa depan.

Dari kesepuluh ciri-ciri tersebut tergambar bahwa, tidak semua orang bisa menjadi pemimpin, karena dibutuhkan banyak persyaratan dan kompetensi diri yang bisa mendukung seseorang utuk menjadi pemimpin. 
Secara umum pelatih sebagai seorang pemimpin yang memimpin para atletatletnya juga harus memiliki karakteristik pemimpi yang harus dikembangkan yaitu: (1) tanggung jawab seimbang, keseimbangan disini adalah antara tanggungjawab terhadap pekerjaan yang dilakukan dan tanggung jawab terhadap orang dalam hal ini atlet yang melaksanakan pekerjaan atau perintah tersebut; (2) model peranan yang positif, peranan disini adalah tanggung jawab, perilaku, atau prestasi yang diharapkan dari seseorang yang memiliki posisi khusus tertentu; (3) memiliki keterampilan komunikasi yang baik, pelatih yang baik harus bisa menyampaikan ide-idenya secara ringkas dan jelas, serta dengan cara yang tepat; (4) memiliki pengaruh positif, pemimpin yang baik memiliki pengaruh terhadap atletnya dan menggunakan pengaruh tersebut untuk hal-hal yang positif dalam upaya peningkatan dan perbaikan prestasi; (5) mempunyai kemampuan untuk meyakinkan orang lain, pelatih yang sukses adalah pemimpin yang dapat menggunakan keterampilan komunikasi dan pengaruhnya untuk meyakinkan orang lain terhadap sudut pandangnya serta mengarahkan mereka pada tanggung jawab total terhadap sudut pandang tersebut.

b. Gaya Kepemimpinan

Gaya Kepemimpinan adalah cara yang digunakan oleh seorang pemimpin yaitu pelatih dalam mempengaruhi atlet (followers) agar mau melaksanakan tugas dan kewajiban sesuai dengan yang diharapkan agar tercapai tujuan yang telah ditentukan sebelumnya. Gaya kepemimpinan menurut Stoner (1994) adalah berbagai polah tingkah laku yang disukai oleh pemimpin dalam mengarahkan dan mempengaruhi bawahannya. Selanjutnya dikatakan juga efektifitas pemimpin juga dipengaruhi oleh berbagai faktor

Gaya kepemimpinan adalah cara-cara khas yang digunakan atau dilaksanakan oleh seseorang dalam rangka menjalankan kepemimpinannya. Masing-masing pemimpin dapat memiliki gaya yang berbeda. Menurut Wahjosumidjo (1993), gaya kepemimpinan adalah sebagai berikut:

1. Gaya kepemimpinan yang berorientasi tugas: 
a. Pemimpin selalu memberikan petunjuk-petunjuk kepada orang yang Dipimpin.

b. Pemimpin selalu mengadakan pengawasan secara ketat terhadap orang yang dipimpin.

c. Pemimpin meyakinkan kepada orang yang dipimpin bahwa tugas-tugas harus dapat dilaksanakan sesuai dengan keinginan pemimpin

2. Gaya kepemimpinan yang berorientasi kepada orang yang dipimpin:

a. Pemimpin lebih memberikan motivasi daripada mengadakan

b. pengawasan terhadap orang yang dipimpin.

c. Pemimpin melibatkan orang yang dipimpin dalam mengambil

d. Keputusan

e. Pemimpin lebih bersikap penuh kekeluargaan, percaya, hubungan kerjasama yang saling menghormati diantara sesama anggota kelompok

Kedua gaya kepemimpinan tersebut menempatkan posisi strategis dari pemimpin yang menitikberatkan kepada sikap pemimpin tesebut dalam mempengaruhi bawahannya untuk mencapai tujuan yang diinginkan.

Selanjutnya Menurut Siagian (2004), terdapat tiga tipe pokok kepemimpinan, yaitu :

a. Tipe Kepemimpinan Otoriter

Tipe kepemimpinan ini menempatkan kekuasaaan ditangan satu orang. Kedudukan dan tugas anak buah semata-mata hanya sebagai pelaksana keputusan dan bahkan pelaksana kehendak pimpinan. Pimpinan memandang dirinya lebih dalam segala hal, dibandingkan dengan bawahannya. 
b. Tipe Kepemimpinan Kendali Bebas

Tipe kepemimpinan ini merupakan kebalikan dari tipe kepemimpinan otoriter. Pemimpin berkedudukan sebagai simbol. Kepemimpinan dijalankan dengan memberikan kebebasan penuh pada orang yang dipimpin dalam mengambil keputusan dan melakukan kegiatan menurut kehendak dan kepentingan masingmasing, baik secara perorangan maupun kelompok-kelompok kecil. Pemimpin hanya memfungsikan dirinya sebagai penasihat.

c. Tipe Kepemimpinan Demokratif

Tipe kepemimpinan ini menempatkan manusia sebagai faktor utama dan terpenting dalam setiap kelompok atau organisasi. Pemimpin memandang dan menempatkan orang-orang yang dipimpinnya sebagai subjek yang memiliki kepribadian dengan berbagai aspeknya, seperti dirinya juga. Kemauan, kehendak, kemampuan, buah pikiran, kreativitas, pendapat, inisiatif yang berbeda-beda dan dihargai disalurkan secara wajar. Kepemimpinan demokratis adalah kepemimpinan yang aktif, dinamis, dan terarah. Kepemimpinan tipe ini dalam mengambil keputusan sangat mementingkan musyawarah, yang diwujudkan pada setiap jenjang dan didalam unit masing-masing.

Ketiga tipe kepemimpinan ini dalam kepelatihan olahraga khususnya dalam implementasi pelatih sebagai pemimpin atlet di lapangan, gaya atau tipe kepemimpinan ini akan berperan dan banyak mempengaruhi dan menjadi ciri khas pelatih dalam menjalankan tugas pelatih khusunya membawa atletnya dalam pencapaian prestasi yang optimal.

\section{Filosofi dan Pelatih Sebagai Pemimpin}

Dalam Undang- undang Sistem Keolahragan Nasional Nomor 3 tahun 2005 dijelaskan tentang pengertian dari olahraga prestasi yaitu" olahraga yang membina dan mengembangkan olahragawan secara terencana, berjenjang, dan berkelanjutan melalui kompetisi untuk mencapai prestasi dengan dukungan ilmu pengetahuan dan teknologi keolahragaan. Kata kunci dari orang yang membinan dan mengembangkan 
olahragawan secara terencana, berjenjang dan berkelanjutan tadi tentunya berada ditangan pelatih. Pelatih adalah tokoh penting dibalik layar dari sebuah prestasi yang fenomenal.

Dalam Kamus Besar Bahasa Indonesia Pelatih diartikan sebagai orang yang melatih dan mengandung kesetaraan atau persamaan kata dengan: guru, instruktur, pembimbing, pengajar, penuntun, penyuluh, tutor, keterkaitan makna kata tersebut dapat dilihat pada gambar sebagi berikut:

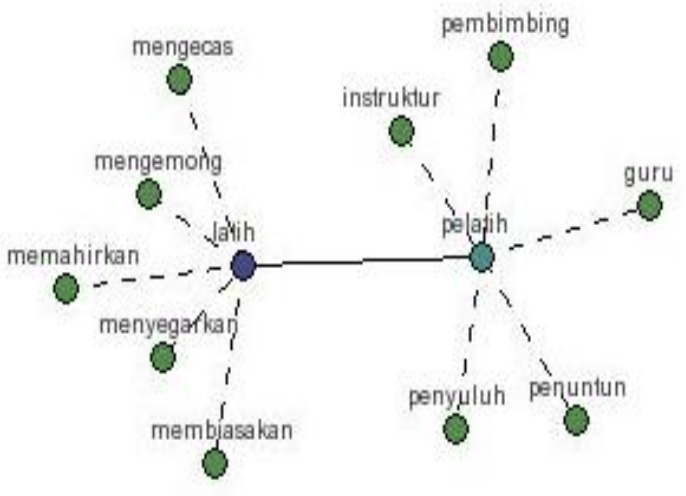

Sumber: www.artikata.com

Maknanya adalah berasal dari kata dasar latih yang mengandung beberapa makna kegiatan diantaranya adalah: mengecas (mengisi), mengemong, memahirkan (keterampilan), menyegarkan (hal yang baru) dan membiasakan. Mengemong berasal dari kata emong yang artinya mengasuh, melayani, mendidik dan mengurus. Pelatih adalah pemimpin yang melayani anak didiknya dan mendidik para atletnya dengan menananmkan karakter-karakter posistif dari nilai-nilai olahraga seperti: disiplin, sportifitas, kerjasama, berani dan bertanggung jawab, kunci dari kesemuanya adalah keteladanan, dimana pelatih dimata atletnya adalah pemimpin dan manusia model yang banyak mempengaruhi dan cas dalam arti disini bisa diartikan memperkuat sentrum atau memancing-mancing merangsang) lebih hidup lagi. Makna dari kata mengecas adalah pelatih adalah pemimpin yang mampu memberikan rangsangan 
positif, membangkitkan energy atletnya, memberikan stimulus dan motivasi kepada atlet untuk berlatih dengan baik dan sunggguh.

Pelatih sebagai pemimpin idealnya merupakan motivator ulung dengan seninya membangkitkan keinginan anak didik untuk terus berlatih, walaupun kadang beban latihan yang diberikan cukup berat, namun dengan kemampuannya dalam mengecas para atlet, sehingga latihan diselesaikan dengan baik dan sungguh-sungguh.

Selanjutnya memahirkan dalam artian menjadikan orang lain menjadi mahir dimana pelatih secara bertahap melakukan latihan-latihan yang sistematis sampai pada akhirnya atletnya memiliki kemahiran yang diginkan atau tingkat tinggi, disini kemahiran dikaitkan dengan keterampilan yang dimiliki berupa teknik- teknik gerakan yang semuanya ditujukan untuk memecahkan tugas gerakan.

Pelatih adalah profesi yang menantang yang melibatkan keputusan yang sulit dan dilema etika. Filosofi yang dibangun dengan baik akan banyak membatu pelatih dalam mengambil keputusan yang sulit dan melatih dengan lebih suskses. Tanpa filosofi yang dikembangan dengan baik, pelatih akan kehilangan arah dan mudah terpeengaruh oleh berbagai pendapat dan tekanan dari luar. Dengan memiliki filosofi akan mampu menghilangkan eraguan tentang berbagai hal seperti, peraturan, gaya bermain, dispilin, kode etik, tujuan baik jangka pendek maupun jangka panjang dan berbagai aspek kepelatihan lainnya. Jika pelatih mampu mberikan porsi waktu yang sama terhadap pengembangan filosofi sebagaimana yang dilakukan terhadap pengembangan pengetahuan teknis olahraga, akan mendorong seseorang untuk menjadi pelatiih yang lebih baik.

Banyak pelatih terkenal karena memiki filosofi kepelatihan yang kuat dan mereka menemukan dalam karir mereka bahwa seni melatih melibatkan pemanfaatan konsep filosofi secara luas untuk meningkatkan pencapaia tujuan . Filosofi terdiri atas:

1) Tujuan utama yaitu hal hal strategis yang ingin dicapai.

2) Kepercayaan atau prinsip yang membantu pelatih mencapai tujuan tersebut 
Dalam membentuk filosofi dalam bentuk karakter yang kuat pada diri seorang pelatih menggunakan berbagai cara, dan berlangsung terus menerus selama bertahuntahun, dimulai dengan pengalaman pribadi saat menjadi atlet, mengamati berbagai macam pertandingan, dan akan berlanjut disaat mempelajari lebih dalam tentang sebuah permainan dan penerapannya kepada atlet. Filosofi pada hakekatnya adalah:

1. Upaya mengejar kearifan yang akan menolong dan menjawab pertanyaan dasar tentang apa, mengapa dan bagaimana.

2. Filosofi menentukan cara/jalan dalam memandang sebuah obyek dan pengalaman dalam kehidupan sebagai anggota masyarakat beserta interaksinya.

3. Filosofi juga menentukan nilai-nilai yang dipegang menjadi pedoman dalam kehidupan.

Salah saatu falsafah penting yang harus dimiliki oleh pelatih adalah menjadi seorang pemimpin yang tahu apa yang dilakukan dan bagaimana melakukannya.. Untuk hal tersebut ada 6 tindakan pelatih untuk menjadi pemimpin efektif daam tugasnya sebagai pelatih yaitu:

1) Pemimpin memberikan arah dan menetapkan tujuan berdasarkan visi dimasa datang

2) Pemimpin yang mampu menciptakan lingkungan sosial dan psikologi yang kondusif untuk mencapai tujuan tim

3) Pemimpin yang menanamkan nilai nilai melalui sharing dengan filosofi hidup mereka

4) Pemimpin yang mampu memotivasi anggota kelompok untuk mncpai tujun tim

5) Memimpin yang mampu mengatasi konflik saat permasalaah muncul

6) Pemimpin yang memiliki kemampuan berkomuniksi yang baik 


\section{KESIMPULAN}

Gelar "coach" atau "pelatih" adalah gelar atau sebutan yang memancarkan rasa hormat, respek, status, tanggungjawab. Gelar coach seringkali bisa berlanjut meskipun tugas sebagai coach sudah usai. Sekali coach selamanya adalah coach bagi atlet, bagi rekan, dan bagi masyarakat. Pelatih pada umumnya telah melewati kiprahnya di dunia olah raga sebagai seorang atlet. Oleh karenanya, ketika menjadi seorang pelatih bagi atlet-atlet cabang olah raga, pelatih harus menjalankan profesinya secara profesional. Saat ini kebanyakan pelatih masih membawakan performance waktu sebagai atlet. Pelatih harus mengilhami dirinya menjadi panutan dan teladan bagi atlet di suatu cabang olahraga. "Pelatih itu adalah tulang punggung cabang olahraga. Jadi, kalau tulang punggung (pelatih) itu sakit, maka atlet juga akan sakit,".

Dengan hadirnya seorang pemimpin dalam sebuah organisasi sosial, atau dalam olahraga hadirnya seorang pelatih diharapkan mereka dapat memberikan teladan yang baik dari sikap dan keperibadian mereka agar apa yang baik dari mereka dapat dicontoh, karena dalam sebuah organisasi ada kecendrungan untuk mencontoh pemimpinnya. Hal ini memeng terbukti, terkadang seorang mantan atlet yang telah beralih profesi menjadi pelatih akan mmemiliki gaya melatih sesuai dengan apa yang pernah ia dapatkan semasa ia menjadi atlet, ia akan mencontoh gaya melatih pelatihnya terdahulu.

Dalam mencapai sebuah prestasi, seorang pelatih yang baik akan mengarahkan para atletnya untuk bersama-sama mencapai prestasi yang telah ditargetkan dengan cara-cara yang positif. Pelatih akan membangun motivasi dan komunikasi yang baik dengan seluruh elemen yang berpengaruh dalam pencapaian prestasi. Tentunya pealtih yang baik dapat mengkoordinir atletnya, dan atletnya akan merasa senang untuk diarahkan dan akan menumbuhkan rasa saling percaya.

\section{DAFTAR PUSTAKA (Rujukan)}


$\checkmark$ Abdul Rahmat, dan Lintje Boekoesoe.2009. Kepemimpinan Gaya, Tipologi dan Praksis.Bandung. MQS Publishing.

$\checkmark$ Australian Coaching Council Incorporated . (1991). Better Coaching Advance coach's Manual. Australian. Australian Sports Commission.

$\checkmark$ Harsono, (1998), Coaching dan Aspek-aspek Psikologi Dalam Coaching. Jakarta: CV. Tambak Kusuma.

$\checkmark$ Harsuki (2003). Perkembangan Olahraga Terkini kajian Para pakar. Jakarta. PT. RajaGrafindo Persada.

$\checkmark \quad$ IOC (2001). Olympic Solidarity, Sports Administration Manual. Laussane. IOC

$\checkmark$ Martens, Rainer. 1995. Successful Coaching. American Sports Education Program

$\checkmark$ Sondang P. Siagian .(2003). Teori dan Praktek Kepemimpinan (cetakan ke lima). Jakarta. Rineka Cipta.

$\checkmark$ Wahjosumidjo, ,1993. Kepemimpinan dan Motivasi. Jakarta: Ghalia Indonesia. 